\title{
Further Developments and Advantages Utilizing Slotted Anodes
}

\author{
Giovanni Campice* \\ T.T. Tomorrow Technology \\ 18 Via Dell'artigianato, Due Carrare (PD), 35020, Italy
}

Received 25.01.2018, received in revised form 29.04.2018, accepted 19.05.2018

\begin{abstract}
Slotted anodes have been used by smelters that require large size anodes. Being inter-anode separations, slots can be considered acting as expansion gaps to safely absorb the heat-induced expansions. The slots are helping to reduce the thermal stresses in the anodes and thus reducing the risk of cracking.

Approach to slots cut in the bottom surface of the anodes has nowadays changed and become extremely important, since they represent effective ways to escape gas continuously formed during Aluminium reduction process, thus reducing the accumulation of gas bubbles underneath the anodes. For this reason the use of slots in the anodes allows to reduce electrical cell resistance as well as to improve cell stability. Slots in the anodes therefore result in reduced electrical power consumption for the Aluminium production.

The depth of the slots is important to ensure that these benefits last throughout the entire life of the anodes ("full-life slots"), while slot shape, which determines the gas escape direction and related areas of influence, is also important to achieve further benefits in pot management.

Cutting slots with reduced width reduces the amount of carbon removed from anodes when slots are cut. Narrow slots are improving specific Aluminum production per anode as well as prolonging anodes cycle time.
\end{abstract}

Keywords: slots, anode, aluminium reduction, slotting machine.

Citation: Campice G. Further developments and advantages utilizing slotted anodes, J. Sib. Fed. Univ. Eng. technol., 2018, 11(4), 401-408. DOI: 10.17516/1999-494X-0062.

(C) Siberian Federal University. All rights reserved

* Corresponding author E-mail address: gcampice@tomorrowtechnology.it 


\title{
Разработка и преимущества
}

\section{использования анодов с пазами}

\author{
Джованни Кампич \\ T.T. Tomorrow Technology \\ Италия, 35020, Due Carrare (PD), Via Dell'artigianato, 18
}

\begin{abstract}
Аноды с пазами используются на алюминиевых заводах, где требуются аноды большого размера. Можно считать, что пазы, являясь внутри анодными разделителями, действуют как тепловые зазоры, чтобы безопасно сглаживать расширения, вызванные изменением температуры. Пазы помогают уменьшить термические напряжения в анодах, тем самым снизив риск образования трещин.

Отнотение к прочедуре прорезки пазов в нижней части анодов сейчас изменилось и становится очень важным, т.к. пазы представляют эффективный способ, чтобы избежать непрерывное газообразование при электролизе алюминия, тем самым снижая накопление газовых пузырей на подошве анодов. По этой причине использование пазов в анодах позволяет снизить электросопротивление электролизера, а также повысить его стабильность. Таким образом, пазы в анодах приводят к снижению потребления электроэнергии при производстве алюминия. Глубина пазов важна, чтобы обеспечить все эти преимущества на протяжении всего срока службы анодов («пазы с полным сроком службыл)), в то время как форма пазов, которая определяет направление отвода газа и связанные области влияния, также является важным параметром, чтобы достичь дополнительных преимуществ при управлении электролизером. При прорезке в анодах пазов с уменьшенной шириной снижается количество выбрасываемого углерода. Узкие пазы повышают удельное производство алюминия в расчете на один анод, а также продлевают срок службы анодов.
\end{abstract}

Ключевые слова: пазы, электролиз алюминия, машина для прорезки пазов.

\section{Advantages from slots cut in baked anodes}

T.T. Tomorrow Technology - the Engineering and manufacturing Company based in Italy - has achieved particular knowledge in anodes cutting/slotting technology. Internal R\&D coupled with a long experience in designing and manufacturing dedicated equipment for anodes cutting, slotting and handling, were the basis to develop the last generation of Automatic Anodes Slots Cutting Machines.

Data collected by Tomorrow Technology from customers using slotted anodes give reference and values of the major operational benefits coming from the use of slotted anodes in Aluminium reduction process. The main advantages obtained by the implementation of slotted anodes are:

- reduced ACD distance (lower voltage drop of 50-100 mV);

- increased pot stability;

- better alumina dissolution;

- Improved current efficiency.

The related major benefits achieved by the use of slotted anodes with direct impact on the Aluminium smelter economics are:

- energy saving (ranging from 0.11 to $0.17 \mathrm{kWh} / \mathrm{kg}$ of produced $\mathrm{Al}$ );

- increased production (which may be computed as 1,3-1,7 \% extra Al production, by increasing line current, since the saved energy is used to raise the line current to produce extra Aluminum). 
In a different approach the alternatives to use gained voltage drop can be:

- reduced energy costs;

- increase of current so that the original energy input is maintained (again with extra Aluminum production).

More operation, safety and environmental benefits also follow after introducing the slotting technology.

In this scenario the depth of slot is important to ensure the benefits can last for the entire anode life (full life slots). Slot shapes are important to achieve further benefits in the pots management thanks to the control of the gas exit direction and related area of influence. The last generation of Anodes Slotting Machines can cut slots up to $450 \mathrm{~mm}$ depth.

Opportunity to reduce the slot width has also important consequences on economics and management of potrooms. The last generation of Anodes Slotting Machines operate to cut slots with blades thickness of $12 \mathrm{~mm}, 10 \mathrm{~mm}$ and $8 \mathrm{~mm}$. Since the weight of carbon lost when anodes are slotted depends on blade thickness, the impact on cells performance and management is considerably in favour of slots cut with thinner blades which reduce the carbon lost while slotting the anodes.

Narrow slots allow to reach higher specific Aluminium production per anode as well as to prolong anodes cycle time. Fig. 1 shows actual slots geometrical parameters in baked anodes as last generation of Anodes Slotting Machines achieves.

Slot profiles are very important to achieve benefits in pot management. The Two Axis Dynamic Slot Cutting (TADSC) - patented by T.T. Tomorrow Technology - applied to the Automatic Slots Cutting Machine allows cutting 3 families of slot profiles, whose main characteristics are illustrated in Fig. 2.

In the situation at Fig. $2 a$ the escape direction of gas released by anodes is almost uncontrolled. The second configuration of slots (Fig. $2 b$ ) starts from a pre-selectable slot depth, ends to a smaller one with a constant inclination. This shape of slots allows to reach preferential direction of gas escape. The interrupted slots profile (Fig. $2 c$ ) clearly prevents gas from exiting from one specific side of anodes.

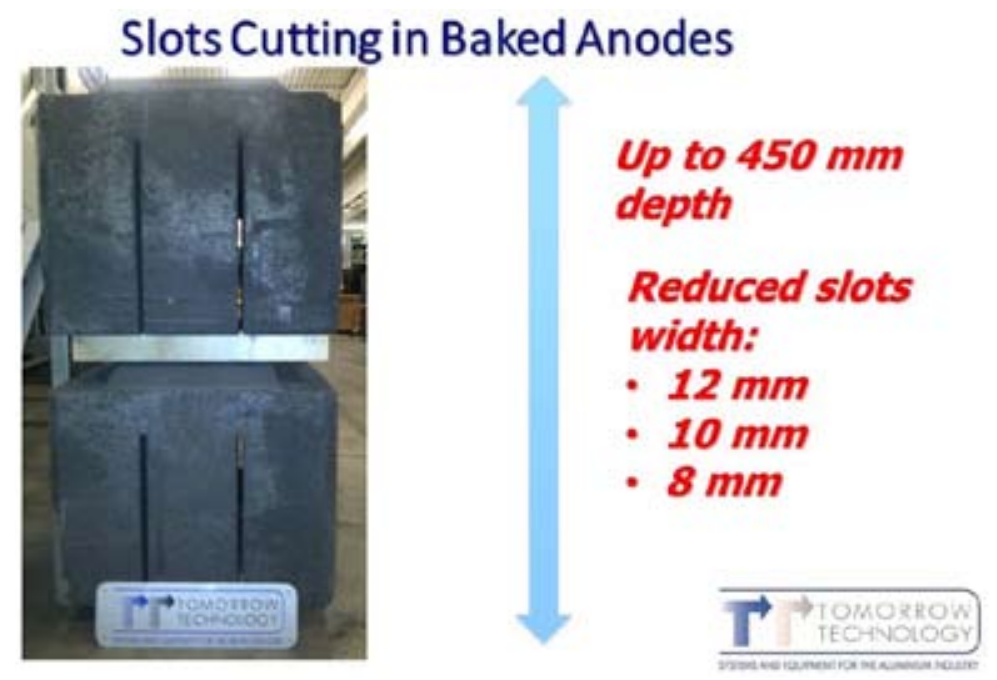

Fig. 1. Narrow and deep slots are cut in baked anodes with last generation of Slotting Machine

$$
-403-
$$




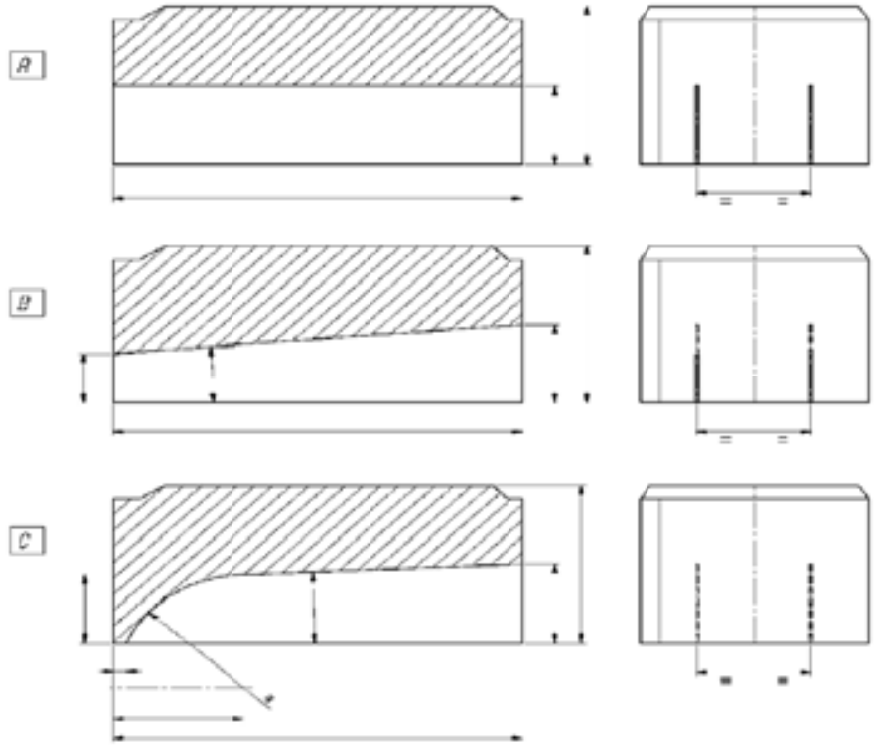

Fig. 2. Profiles of slots cut in baked anodes: $a$ - straight slots (passing through the anode at the same depth); $b-$ inclined slots; $\mathrm{c}$ - interrupted slot (when the slot is not cut through both anode ends)

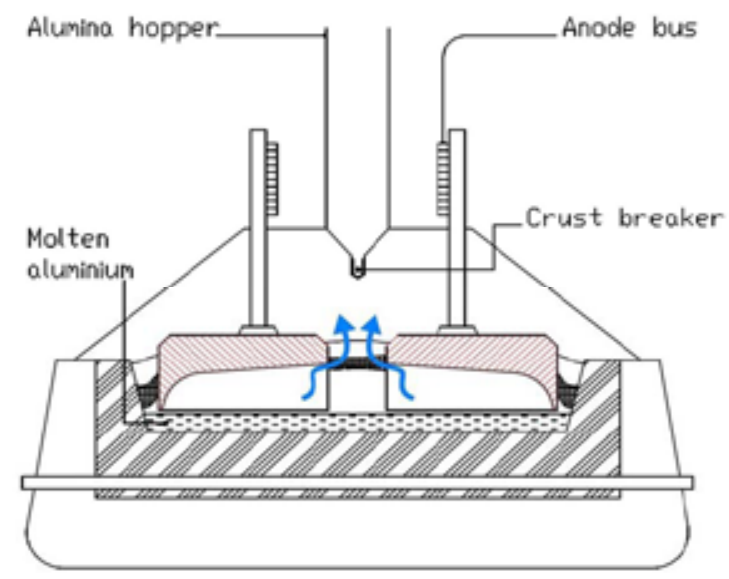

Fig. 3. Anodes with interrupted slots in electrolysis pot with gas excaping towards the center

Particular considerations apply to conditions of interrupted slots in the pot with gas exit direction toward the centre of the pot (Fig. 3).

As it is well known, alumina is fed into the bath during cell operation and it is important to have good alumina dissolution. The anode gas released during electrolysis can be used to create a turbulence in the alumina feeding zone to help its dissolution and to reduce alumina agglomeration.

Interrupted slots with proper orientation are important to create a good turbulence by anodes gas to the extent favourable to increase alumina dissolution.

Interrupted slots are a means to facilitate gas bubbles movement rapidly to the centreline of the reduction cell to expedite dissolution of alumina. At the same time, the slots allow to operate the pots 
at a lower pot noise and reduced pot voltage and therefore lower power consumption and higher current efficiency.

For the above reasons the interrupted slots are cut in the anodes in such a manner as to direct flow gas to the centreline of the reduction cell to expedite the dissolution of alumina. Facilitating the gas flow toward the center of the reduction cell gives operation advantages while increasing efficiencies.

Conveying gas in the centre of the pots results furthermore in less erosion to the reduction cell sidewalls, thus increasing cell life. In a pot with anodes without slots gas flow is from the anode, through the low resistant liquid bath almost in an uncontrolled way. Typically, this may lead to dangerous conditions at side walls of the pot, modifying thermal balance and disturbing the side ledge. Again implementation of interrupted slots in anodes to convoy gas toward the centreline of the pots results beneficial for the pot operations and cells life.

In addition to the economic benefits of the increased Aluminium production - directly resulting from the reduced ACD distance-, Smelters using Anodes Slots Cutting Machines are confirming that the slots give also the following operation improvements:

- increased pot stability;

- Improved current efficiency;

- better alumina dissolution;

- reduced (almost eliminated) number of anode effects (thus limination of harsh environment and risk operations);

- reduction of greenhouse gases and $\mathrm{CO} 2$ emissions.

\section{Economic returns from slots in the anodes}

Implementation of Anodes Slotting projects represents investments with short paybacks. Reduced supply lead-time from the contract award to the commencement of the production at client sites makes faster the commencement of the economic advantages. It is easy to simulate the economic results coming from the use of slotted anodes.

Typical payback calculations for the implementation of a new Anodes Slotting Line even in smelters with production capacity in the range of 250.000 - 300,000 tons per year of Aluminium show pay back between 7 and 12 months.

Since short pay backs (as we may consider if less than one year) are usually more difficult to happen at "small" production capacities, above mentioned results represent indeed a considerably profitable investment starting also from smelters whose production capacity is not so big. Smelters with bigger production capacities are enjoying further positive scale factors.

In this scenario the slot height has a direct impact on specific benefits, since their final amount depends directly on the slot height. The pay back time of the investment is shortened by the higher slots height.

This is the leading point for smelters when moving from the (short and wide) slots formed in the green anodes to the higher and narrower slots cut after anodes are baked.

Recognised benchmark is now to have slots whose height allows to prolong their positive effects during the entire anodes life. Slots width (often said "thickness") is, as a matter of facts, a measure of the carbon "lost" (i.e. not going to the pots). Reduction of slot width (or thickness), therefore, leads

$$
-405-
$$


to maximize productivity of the cells, while prolonging anodes cycle time. With last generation of Anodes Slotting Machines it is now possible to cut slots in baked anodes up to $450 \mathrm{~mm}$ depth with $8 \mathrm{~mm}$ width only. Fig. 4 shows one of the last generation Anodes Slotting Machine while cutting slots $450 \mathrm{~mm}$ height and $8 \mathrm{~mm}$ width.

The opportunity to cut baked anodes with deeper and narrower slots $(450 \mathrm{~mm}$ depth and $8 \mathrm{~mm}$ width, as above mentioned) as a matter of facts is opening new scenarios and presents new opportunities for investments justified by high economic returns.

Several calculations of the Return of Investment and of the pay back period of new investment for new Anodes Slotting Machines to replace former slotting equipment (even if still in working conditions) give evidence of the high profitability of these choices. The price increasing trend of Aluminium at LME (as of December 2017) is magnifying the economic return from above mentioned investments.

Fig. 5 shows anodes slotted with deep and narrow slots before and after being in the pot.

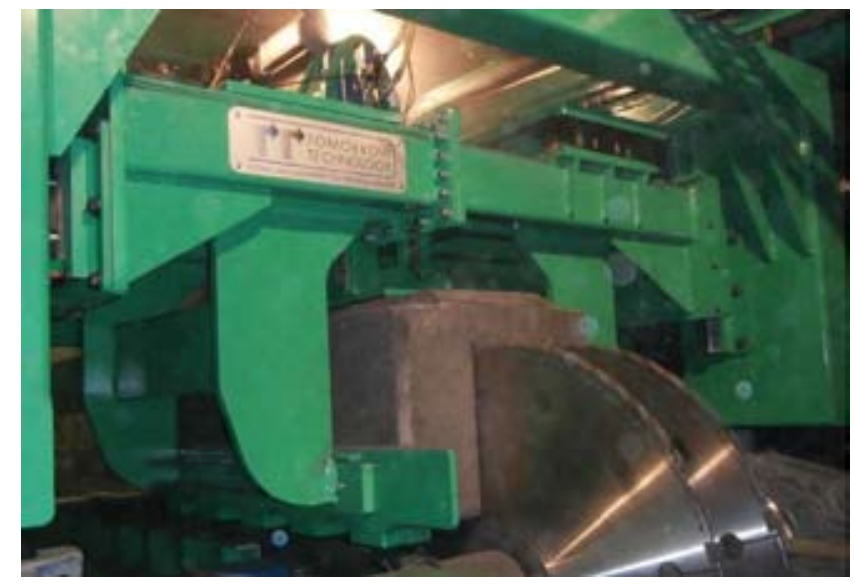

Fig. 4. Last generation of Automatic Anodes Slotting Machine in operation

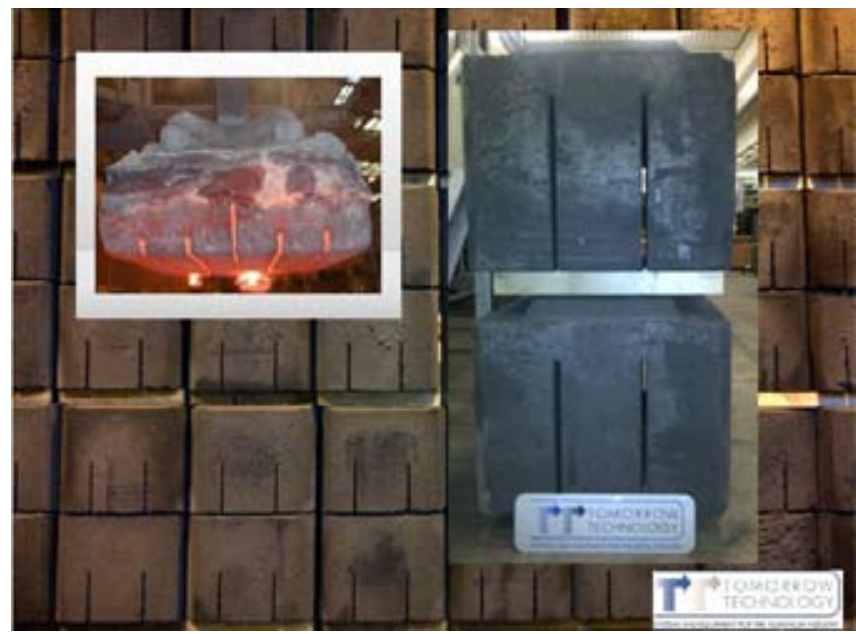

Fig. 5. Slotted anodes at end of life and before being put in operation 


\section{Alternatives analysis (formed slots vs. cut slots)}

Traditionally there are two methods of introducing slots into anodes:

- forming the slots in the green anodes by means of special moulds in the anodes vibro compactor;

- cutting slots in the anodes after the baking process.

The first method - while only apparently cheaper - results in increased waste of anodes for unsatisfactory quality before they they may reach the cells properly and suffers of intrinsic limits in dimensions (short and wide slots reduce current density and limit slot life in the cells) and anodes characteristics (lower and non-homogeneous physical parameters).

The second method (i.e. cutting slots in the anodes after the baking process) allows overpassing the limits and the cons of the slots formed in the green anodes.

Often Anodes Slotting Machines have been installed where previously slots were formed in the green anodes; comparing with slots cut in baked anodes, the following key points may be summarized in the Table below.

It is easy to calculate how the weight of carbon lost with slots formed in green anodes is much higher than carbon lost when anodes are slotted after baking. If we compare the same slots height, the carbon lost when slots are formed at the green phase may be up to 3 times the amount which is lost cutting slots in baked anodes; the impact on cell performance and management is therefore considerably in favour of slots cut in baked anodes, which furthermore are not suffering any density issue. Slots cut in baked anodes are helping to reduce carbon consumption if compared with anodes slotted while green, since typical disadvantages of slotted green anodes are avoided; particularly $\mathrm{CO}$ and $\mathrm{CO} 2$ attack in slotted green anodes is higher due to reduced apparent density and increased air permeability.

\section{Conclusions}

Short pay back quickly starts after short delivery time and smooth implementation where the last generation of Automatic Anodes Slotting Machines manufactured by T.T. Tomorrow Technology are in operation.

Slots are successfully cut in baked anodes up to $450 \mathrm{~mm}$ depth and 12,10 or $8 \mathrm{~mm}$ width.

In addition to the very high economic benefits of increased Aluminium production, smelters using Anodes Slots Cutting Machines are gaining further operational advantages.

Table. Comparison of slots formed in green anodes vs. slots cut in baked anodes

\begin{tabular}{|l|l|l|}
\hline & \multicolumn{1}{|c|}{ Slots formed in green anodes (typical) } & \multicolumn{1}{|c|}{ Slots cut in baked anodes } \\
\hline Orientation & $\begin{array}{l}\text { Tied to anodes exit direction from the } \\
\text { mold }\end{array}$ & No limitation \\
\hline Slot width & $\begin{array}{l}25-40 \mathrm{~mm} \text { (at base) to } \\
10-20 \mathrm{~mm} \text { (at top) }\end{array}$ & $12-10-8 \mathrm{~mm}$ (constant) \\
\hline Slot height & $150-300 \mathrm{~mm}$ & Up to $450 \mathrm{~mm}$ \\
\hline Anode density & $\begin{array}{l}\text { Not homogeneous (affected by plates to } \\
\text { form slots), lower }\end{array}$ & $\begin{array}{l}\text { Higher, homogeneous (not affected by } \\
\text { slots) }\end{array}$ \\
\hline
\end{tabular}


We can conclude that the implementation of anode slotting technology allows paybacks ranging within short periods, even for smelters with smaller production capacity. It results in increased production capacity and minimizes production costs; while paying importance to safeguarding energy energy resources, it leads to reducing environmental impact.

The opportunity to cut slots with interrupted profile (as to forward released gas toward the centre of the pots), to increase slot depth and reduce the width is justifying new investments to replace old slotting equipment already in operation; appraisals of that are considering the benefits of deeper and narrower slots give evidence of high profitability even in case of replacement of existing equipment in operation at lower performances level.

The article is based on the paper presented at the IX International Congress "Non-ferrous metals and minerals-2017”. 